\title{
KONSTRUKSI PEMBINGKAIAN PERATURAN DAERAH NOMOR 2 TAHUN 2010 PADA BERITA KASUS IBU SAENI VERSUS SATUAN POLISI PAMONG PRAJA DI KOMPAS.COM DAN REPUBLIKA.CO.ID
}

\author{
Laksmi Rachmaria, Indah Suryawati \\ Fakultas Ilmu Komunikasi Universitas Budi Luhur \\ laksmi.ozil@gmail.com \\ indahsuryawati_2121@yahoo.com
}

\begin{abstract}
This study aims to determine how the construction of the framing of Perda No.2 Tahun 2010 on the news carried by Kompas.com and Republika.co.id related to the case of Ibu Saeni versus Satpol PP. This study used a qualitative approach to framing analysis method Robert N. Entman. The results showed that the framing is done Kompas.com news brought into the realm of human rights. Ibu Saeni positioned as a victim, Perda No. 2 Tahun 2010 and Satpol PP as the cause of the problem. Kompas.com use moral claim form Indonesia Country pruralis with the motto Unity in Diversity, not a Muslim country. Problem resolution recommended be abolished Perda No. 2 Tahun 2010. Republika.co.id framing the case of Ibu Saeni to the moral realm. Republika.co.id positioned Perda No. 2 Tahun 2010 as well as Satpol PP as victims and the media as the cause of the problem. Moral claim form used Republika.co.id let Banten care of 'household' own party outside the province do not have to intervene. treatment recommendation) be maintained Perda No.2 Tahun 2010.
\end{abstract}

Keywords: Framing, News, Ibu Saeni vs Satpol PP

\section{PENDAHULUAN}

Ramadhan tahun ini diawali dengan ramainya pemberitaan seputar kontroversi Peraturan Daerah No.2 Tahun 2010 tentang Pencegahan, Pemberantasan, dan Penanggulangan Penyakit Masyarakat yang berlaku di kota Serang, Banten, Jawa Barat. Meski sudah berlaku selama enam tahun, baru tahun ini Peraturan Daerah (Perda) yang dibuat oleh eksekutif dengan persetujuan legislatif ini menuai konflik.

Ibu Saeni, pemilik warung nasi yang terkena razia Satuan Polisi Pamong Praja (Satpol PP) menangis histeris ketika dagangannya disita aparat Satpol PP Serang Jum'at, 10 Juni 2016 lalu. Perempuan berusia 50 tahun itu dianggap telah melanggar aturan pemerintah daerah terkait larangan warung makan buka di siang hari selama bulan Ramadhan. Padahal 
berita-berita seputar razia warung makan yang buka di siang hari pada bulan Ramadhan sebetulnya bukanlah hal yang baru, bahkan seolah merupakan "menu rutin" di setiap bulan Ramadhan. Namun kasus Ibu Saeni telah menyedot perhatian media massa, terutama media online hingga mampu mengaduk emosi khalayak.

Kasus Ibu Saeni vs Satpol PP Pemkot Serang tiba-tiba menjadi sorotan khalayak. Berawal saat Kompas TV menyiarkan sebuah adegan pengambilan paksa barang dagangan dari warung Ibu Saeni. Framing wajah iba Ibu Saeni dengan linangan air matanya menghiasi layar kaca.

Namun meski melanggar aturan, Ibu Saeni mendapat simpati dari sebagian khalayak pasca pemberitaan yang dimuat di media massa maupun media online. Dwika Putra, seorang netizen dengan akun twitter @dwikaputra melakukan penggalangan dana publik dengan tujuan membantu korban penertiban. Penertiban yang dilakukan satpol PP tersebut dinilai sebagian kalangan telah mencederai nilai-nilai kemanusiaan. Jumlah dana yang terkumpul pun cukup besar. Hingga penggalangan resmi ditutup, yakni Minggu 12 Juni 2016 pukul 12.00 WIB jumlah dana yang terkumpul sebesar Rp. 265.534.758 dari 2.427 donasi.

Dari sisi jurnalistik, kasus Ibu Saeni memiliki nilai berita seperti konflik, human interest, impact (akibat), informasi, penting dan aktual, sehingga tidak mengherankan jika media massa dan media online pun beramai-ramai meliput peristiwa tersebut.

Berita adalah hasil konstruksi sosial yang selalu melibatkan pandangan, ideologi, dan nilai-nilai dari wartawan atau media (Eriyanto, 2002:29). Secara sederhana semakin besar peristiwanya semakin besar pula dampak yang ditimbulkannya.

Berita dalam pandangan konstruksionis diibaratkan sebagai sebuah drama. Berita tidak menggambarkan realitas, melainkan potret dari arena pertarungan antara berbagai pihak yang berkaitan dengan peristiwa. Mereka (media) berusaha untuk menonjolkan kerangka pemikiran, perspektif, konsep dan klaim interpretatif masing-masing dalam memaknai objek wacana.

Seseorang bisa ditampilkan atau diceritakan sebagai pahlawan ataupun penjahat, bergantung pada bagaimana media memahami dan memaknai peristiwa tersebut dan bagaimana fakta yang ada dikonstruksi menjadi sebuah berita.

Media dapat memilih realitas mana yang akan ditampilkannya dan menyembunyikan realitas yang diinginkannya. Pilihan kata-kata tertentu yang dipakai media tidak sekadar sebagai bagian dari tekhnik jurnalistik, akan tetapi lebih kepada politik bahasa. Semua aspek yang dipakai untuk membuat dimensi tertentu dari sebuah konstruksi berita menjadi 
lebih bermakna dan diingat oleh khalayak, sehingga pemahaman dan konstruksi atas peristiwa yang sama bisa jadi berbeda antara satu media dengan media lainnya.

Melalui portal berita

Kompas.com dan Republika.co.id peneliti berusaha melihat bingkai yang digunakan oleh kedua media, sehingga dapat dilihat kecenderungan masingmasing media karena perbedaan visi dan misi ataupun latar belakang sejarah berdirinya media tersebut.

Konsep ideologis menurut pendekatan konstruksionisme dapat membantu menjelaskan bagaimana wartawan bisa membuat liputan berita memihak satu pandangan, menempatkan satu pandangan lebih menonjol dibandingkan pandangan kelompok lain dan sebagainya. Hal ini dipandang sebagai sesuatu yang wajar dan alami. Praktik-praktik ini mencerminkan ideologi dari si wartawan atau media tempat ia bekerja.

Kompas.com sebagai bagian dari Kompas Gramedia Grup memiliki visi dan misi menjadi perusahaan yang terbesar, terbaik, terpadu dan tersebar di Asia Tenggara melalui usaha berbasis pengetahuan yang menciptakan masyarakat terdidik, tercerahkan, menghargai kebhinekaan dan adil sejahtera.

Republika.co.id sebagai portal berita hadir sejak 17 Agustus 1995 dari kalangan komunitas muslim bagi publik Indonesia. Republika dalam sejarah berdirinya juga didukung oleh Ikatan Cendikiawan Muslim Indonesia.

Wartawan bukanlah robot yang meliput apa adanya atas apa yang Ia lihat, Ia temukan di lapangan. Ada faktor etika, moral atau keyakinan pada kelompok atau nilai tertentu yang merupakan bagian yang integral dan tidak terpisahkan dan membentuk sekaligus juga mempengaruhi saat mengkonstruksi realitas.

Berdasarkan latar belakang
tersebut peneliti ingin melihat bagaimana konstruksi Perda No.2 tahun 2010 pada pemberitaan Ibu Saeni vs Satpol PP Pemkot Serang, Banten di Kompas.com dan Republika.co.id?

\section{TINJAUAN PUSTAKA}

\section{Konstruksi Realitas}

Media massa sebagai lembaga sosial telah tumbuh sebagai industri jasa yang melayani informasi masyarakat. Media massa dikontrol dengan ketat oleh pemilik modal (pengusaha) dengan manajemen yang rasional dan professional. Media massa bukanlah alat yang pasif, melainkan aktif, karena memiliki kepentingan dan kepribadian tersendiri yang disebut "politik redaksi" (Tamburaka, 2012:89).

Berita yang kita baca bukan hanya menggambarkan realitas. Eriyanto menjelaskan bagaimana konstruksi realitas pada media massa, sebuah teks berupa berita tidak bisa dipandang sebagai cerminan realitas. Ia haruslah dipandang sebagai konstruksi 
atas realitas, karenanya sangat potensial terjadi peristiwa yang sama dikonstruksi secara berbeda (Eriyanto,2002:17).

Fakta diproduksi dan ditampilkan secara simbolik, sehingga realitas tergantung pada bagaimana ia dilihat dan bagaimana fakta tersebut dikonstruksi (Eriyanto, 2002:21)

Untuk melihat hubungan antara beragamnya faktor dan agenda media massa, Shoemaker dan Reese (dalam Vera, 2010:120) menganalogikannya seperti lingkaran yang berlapis-lapis pada onion (bawang merah)

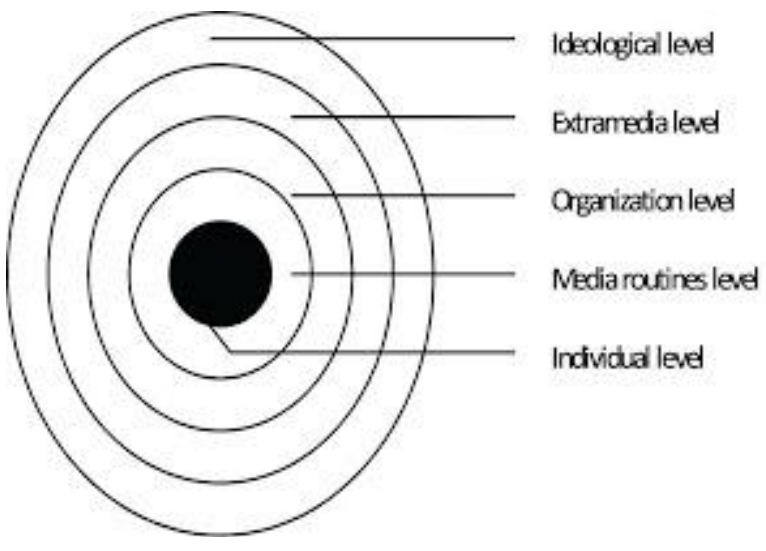

Gambar 1 model Hirarki Isi Pesan Media Shoemaker and Reese

Keterangan:

1. Level Individu; yaitu para pekerja media seperti wartawan, reporter, dan lain-lain yang mempunyai peranan sangat penting dalam penentuan isi media, karena merekalah yang terlibat langsung dalam mencari berita dan menyaksikan langsung sebuah realitas yang akan dilaporkannya.

2. Level rutinitas media; kegiatan sehari-hari yang berlangsung dalam institusi media. Menyangkut pada proses manajemen media khususnya produksi media. Para pekerja media dalam melaporkan hasil temuannya biasanya tunduk pada rutinitas media, yakni praktikpraktik media dimana keputusan dan persepsi mengenai peristiwa yang dibawa jurnalis ke ruang pemberitaan dipengaruhi oleh cara professional media di perusahaan di mana mereka bekerja mengorganisasikan sistem kerja mereka.

3. Level organisasi media; disamping rutinitas media, organisasi media juga ikut terlibat dalam proses rekonstruksi berita atau peristiwa. Pada level ini organisasi sebagai perangkat struktur industri media, ikut menentukan proses rekonstruksi peristiwa yang terjadi, dan biasanya disesuaikan dengan ideology serta visi-misi media yang bersangkutan.

4. Level ekstra media; mempersoalkan sumber-sumber informasi media, pengiklan, khalayak sasaran, ataupun pasar media.

5. Level Ideologi; faktor ideologi mempersoalkan berbagai sistem kepercayaan, nilai, dan makna yang digunakan oleh media massa untuk menentukan isi yang akan 
ditampilkan. Aspek ideologi adalah eksternal media yang berkaitan dengan sistem pers suatu Negara

\section{Teori Framing (Robert N. Entman)}

Framing adalah pendekatan untuk melihat bagaimana realitas itu dibentuk dan dikonstruksi oleh media, dimana hasil akhirnya adalah adanya bagian tertentu dari realitas yang menonjol dan lebih mudah dikenal (Eriyanto, 2002:66)

Framing merupakan metode penyajian realitas dimana kebenaran itu tidak diingkari secara total, melainkan "dibelokkan" secara halus dengan cara memberikan penonjolan pada aspek tertentu. Aspek-aspek yang disembunyikan oleh media kemudian menjadi terlupakan bahkan tidak diperhatikan sama sekali oleh khalayak.

Entman melihat framing dalam dua dimensi besar: seleksi isu dan penekanan atau penonjolan aspek.

Dalam konsep Entman, framing pada dasarnya merujuk pada pemberian definisi, penjelasan, evaluasi dan rekomendasi dalam suatu wacana untuk menekankan kerangka berfikir tertentu terhadap peristiwa yang diwacanakan.

Konsep mengenai framing dari Entman tersebut menggambarkan secara luas bagaimana peristiwa dimaknai dan ditandakan oleh wartawan. Entman membagi perangkat framing kedalam empat elemen sebagai berikut:

1. define problems (pendefinisian masalah) elemen ini merupakan master frame/bingkai yang paling utama. Ia menekankan bagaimana peristiwa dipahami oleh wartawan, bagaimana peristiwa atau isu tersebut dipaham. Peristiwa yang sama dapat dipahami dengan cara dan bingkai yang berbeda.

2. diagnose causes (memperkirakan penyebab masalah), merupakan elemen framing untuk membingkai siapa saja yang dianggap sebagai aktor dari suatu peristiwa. Penyebab di sini bisa what (apa) atau who (siapa).

3. make moral judgement (membuat keputusan moral) adalah elemen framing yang dipakai untuk membenarkan/memberi

argumentasi pada pendefinisian masalah yang sudah dibuat.

4. treatment recommendation (menekankan penyelesaian) elemen ini dipakai untuk menilai apa yang dikehendaki oleh wartawan. Jalan apa yang dipilih untuk menyelesaikan masalah. Penyelesaian itu tentu saja sangat tergantung pada bagaimana peristiwa itu dilihat dan siapa yang dipandang sebagai penyebab masalah (Eriyanto, 2002:225).

Sebuah realitas yang disusun secara menonjol akan memungkinkan peluang realitas itu untuk diperhatikan dan mempengaruhi khalayak dalam memahami realitas tersebut. Penonjolan di sini adalah bagaiman wartawan membuat informasi yang ada menjadi 
lebih menarik, lebih bermakna, berarti atau lebih mudah diingat oleh khalayak.

\section{METODE PENELITIAN}

Penelitian ini menggunakan pendekatan penelitian kualitatif dengan metode analisis framing Robert $\mathrm{N}$. Entman. Pendekatan kualitatif bertujuan untuk mendapatkan data-data deskriptif melalui kata-kata maupun kalimat. Penelitian kualitatif menekankan realitas yang dibangun secara sosial, hubungan yang intim antara peneliti dengan yang dipelajari dari kendala situasional yang membentuk penyelidikan (Salim, 2001:11).

Pendekatan kualitatif menurut Rachmat Kriyantono (2006:11), merupakan pendekatan yang bertujuan menjelaskan fenomena-fenomena yang sedalam-dalamnya melalui pengumpulan data yang selengkaplengkapnya. Riset ini tidak mengutamakan besarnya populasi sampling.

HASIL PENELITIAN DAN PEMBAHASAN

Frame Pemberitaan Kompas.com

Define Problem (pendefinisian masalah), Portal berita Kompas.com mendefinisikan kasus Penertiban Warung Ibu Saeni vs Satpol PP ke ranah HAM. Segala sesuatu dari kasus Penertiban Warung Ibu Saeni vs Satpol PP disoroti dari segi HAM, bukan moral ataupun politik. Nara sumber yang dimuat Kompas.com untuk memperkuat bingkainya terdiri dari berbagai kalangan mulai dari artis, cendikiawan muslin, menteri dalam negeri, semuanya berbicara dalam konteks HAM, antara lain Jusuf Kalla (Wapres RI),Sophia Latjuba (artis peran), Muhammad Syafi'Ali (Intelektual muda Nahdlatul Ulama), Tjahjo Kumolo (Menteri Dalam Negeri), Ade Komarudin (Ketua DPR).

\section{Diagnose Causes (Penyebab}

Masalah), dalam keseluruhan berita Kompas.com, penyebab masalah dalam kasus ini adalah Perda No.2 tahun 2010 tentang Pencegahan, Pemberantasan dan Penanggulangan Penyakit Masyarakat (Pekat), dimana salah satu butir dalam perda tersebut berisikan tentang larangan rumah makan beroperasi saat Ramadhan pada jam tertentu. Perda ini dianggap bermasalah karena dinilai diskriminatif dan mencederai toleransi. Hal ini dapat trlihat dalam teks berita berikut:

Warung makanan dirazia? Bukannya Indonesia negara Bhinneka Tunggal Ika ya? Bukannya kita negara hukum? Memang Indonesia mayoritas Islam, tapi kita bukan negara Islam," tulis Sophia melengkapi keterangan video yang diunggahnya pada akun Instagram @ sophia_latjuba88, Sabtu (11/6/2016).

Hargailah yang tidak puasa juga. Hargailah yang mencari nafkah secara legal dan sah. Menurut saya puasa itu satu keputusan individu dan mestinya bukan 
satu pemaksaan. Kalau saya memaksa orang di sebelah saya untuk tidak makan sewaktu saya puasa, apakah itu adil dan sah dan mencerminkan ibadah saya yang suci dan semestinya?" lanjut kekasih vokalis Ariel "NOAH" itu.

Banyak orang yang sedang dalam perjalanan dari luar kota dan mereka tdk puasa. Banyak sekali alasan yang diperbolehkan untuk tidak puasa, apalagi yang beda agama. Masa ibu ini tidak boleh menyediakan makanan untuk orang-orang tersebut? Bagaimana pendapat kamu? (Sophia Latjuba Protes Razia Warung Makan di Bulan Ramadhan, Sabtu, 11 Juni 2016 15:29)

Pada teks berita ini, penulis berita mencoba untuk memperkuat bingkainya dengan cara menggunakan penonjolan pada aspek-aspek tertentu, seperti melalui kata, kalimat, gambar atau foto dari citra tertentu.

Penulis berita memilih mengambil kutipan kalimat yang ditulis oleh Sophia Latjuba berupa kata-kata seperti Negara Bhinneka Tunggal Ika; Bhinneka Tunggal Ika merupakan moto atau semboyan Bangsa Indonesia. Kalimat ini berasal dari bahasa Jawo Kuno dan sering kali diterjemahkan dengan kalimat berbeda-beda tetapi tetap satu. Secara harfiah Bhinneka Tunggal Ika diterjemahkan "Beraneka Satu Itu". semboyan ini digunakan untuk menggambarkan persatuan dan kesatuan Bangsa dan Negara Kesatuan Republik Indonesia yang terdiri atas beraneka ragam budaya, bahasa daerah, ras, suku bangsa, agama dan kepercayaan. Penulis berita juga menggunakan penonjolan aspek berupa frasa Negara hukum yang artinya Negara yang menjadikan hukum sebagai kekuasaan tertinggi. Penonjolan aspek lain ada pada frasa bukan Negara Islam. Negara Islam merupakan Negara dimana setiap perilaku politiknya didasarkan atas nilai-nilai atau ajaran agama Islam yang bersumber pada $\mathrm{Al}$ Qur'an dan Hadis Nabi Muhammad SAW.

Kompas.com juga mempertegas bingkainya yang dapat terlihat dalam teks berita berikut:

Intelektual muda Nahdlatul Ulama (NU) Muhammad Syafi' Ali atau yang biasa disapa Savic Ali menilai bahwa larangan warung buka siang hari di bulan Ramadhan oleh Pemkot Serang justru bisa merusak citra agama Islam dan mengganggu iklim toleransi di masyarakat.

Dengan larangan tersebut, kata Savic, seolah-olah Islam dicitrakan sebagai agama yang selalu melahirkan paksan-paksaan bagi setiap orang. "Ini memperburuk citra Islam yang membuat seolah-olah Islam ini adalah agama yang selalu memaksa orang,"ujar Savic saat dihubungi Kompas.com, Sabtu (11/6/2016).

Savic juga mengingatkan, Indonesia merupakan negara 
pluralistis yang masyarakatnya terdiri dari berbagai suku dan agama. (Larangan Warung Buka Saat Bulan Puasa Dinilai Merusak Citra Islam dan Toleransi, Sabtu, 11 Juni 2016)

Pada teks berita ini Kompas.com mengambil pernyataan dari salah satu Organisasi Islam di Indonesia, Nahdlatul Ulama, Muhammad Syafi' Ali untuk memperkuat bingkainya. Kompas.com memberikan predikat Intelektual muda. Kata intelektual sendiri berarti cerdas, berakal dan berpikiran jernih berdasarkan ilmu pengetahuan.Kompas.com juga menggunakan frasa merusak citra, mengganggu iklim (keadaan/suasana) toleransi, dan kata memaksa memperlakukan, menyuruh, meminta dengan paksa. Penonjolan-penonjolan tersebut merupakan cara yang dilakukan Kompas.com untuk meyakinkan khalayaknya bahwa ada yang salah dari Perda No.2 tahun 2010 tersebut. Perda ini dianggap sebagai perda yang intoleran.

Selain perda No.2 tahun 2010 yang dianggap sebagai penyebab masalah, Kompas.com juga memposisikan Satpol PP kota Serang sebagai penyebab masalah. Aparat pemerintah ini dianggap telah bertindak berlebihan dan mencederai nilai-nilai kemanusiaan. Hal ini dapat terlihat dalam teks berita berikut:

Aksi Satpol PP ini mendapat kecaman dari berbagai pihak. Dalam akun instagram artis Sophia
Latjuba mengingatkan Indonesia adalah Negara Bhinneka Tunggal Ika

...eskalasi yang meningkat juga mendorong Wapres Jusuf Kalla untuk angkat bicara. Wapres menyebut tindakan penyitaan tersebut merupakan tindakan semena-mena. (Polemik Razia Warung Nasi, Minggu, 12 Juni 2016 11:12)

Yang eksekusi kadang berlebihan. Seharusnya cukup dilakukan penyuluhan warung makan, yang puasa harus dihormati, jangan terbuka, harus ada tirainya,"..(Dalam Kasus Saeni, Eksekusi Perda Dinilai Mendagri Berlebihan, Senin, 13 Juni 2016 18.30)

Ketua Dewan Perwakilan Rakyat Ade Komarudin mengatakan, imbauan untuk menghormati orang berpuasa harus dilakukan dengan cara yang persuasif.

Dia menyatakan hal tersebut terkait dengan aksi penutupan warung makan oleh Satuan Polisi Pamong Praja (Satpol PP) Kota Serang, Banten.

"Menghormati orang berpuasa dilakukan secara persuasif, tidak boleh melukai orang lain, apalagi orang lain itu sesama WNI," kata Akom, sapaan Ade, seusai menjalani buka puasa di rumah dinas Akom, Jakarta, Senin (13/6/2016). (Ketua DPR:

Menghormati yang Berpuasa, Jangan Sakiti Orang Lain, Selasa 14 Juni 2016 11:16) 
Salah satu warga yang terkena razia adalah Saeni (53), warga Kabupaten Serang yang berjualan nasi di warung makan miliknya pada siang hari.

"Bahwa dalam melaksanakan instruksi kepala daerah atau melaksanakan peraturan daerah harus bersikap simpatik, mengedepankan penyuluhan, tidak over acting, dan menimbulkan tidak simpatiknya masyarakat kepada pemerintahan baik pusat maupun daerah," tulis Tjahjo dalam keterangan tertulisnya, Minggu(12/6/2016).

(Mendagri:Satpol PP Jangan "Over Acting" Dan Sok Kuasa)

Selain mendefinisikan penyebab masalah, Kompas.com juga memposisikan Ibu Saeni, pemilik warung nasi yang terkena razia Satpol PP Serang sebagai korban, hal ini dapat terlihat dalam teks berikut:

Sebelumnya

diberitakan, seorang ibu pemilik warung makan di Kota Serang, Banten, menangis ketika dagangannya disita aparat Satuan Polisi Pamong Praja (PP) Pemkot Serang, Jumat (19/6/2016).

Namun tangisan ibu tersebut tak

dihiraukan. Aparat tetap mengangkut barang dagangan ibu tersebut. Kepala Satpol PP Maman Lutfi kepada Kompas TV mengatakan, warung tersebut kena razia karena buka siang hari dan melayani warga yang tidak puasa.
Dalam razia itu, petugas menertibkan puluhan warung makan yang buka siang hari. Semua dagangannya disita. Sementara itu, beberapa pemilik warung beralasan buka siang hari karena tidak tahu ada imbauan larangan buka siang hari di bulan Ramadhan. Sebagian lagi buka warung karena butuh uang untuk menghadapi Lebaran. (Larangan Warung Buka Saat Bulan Puasa Dinilai Merusak Citra Islam dan Toleransi)

Di sini, Kompas.com ingin membangun konstruksi tentang sosok Ibu Saeni, perempuan tua yang tiada daya. Karena ketidakmampuannya dalam membaca (buta huruf) ia "terpaksa" melanggar aturan yang ada, padahal Saeni "dinilai" Kompas.com tidak tahu akan aturan larangan tersebut.

\section{Make Moral Judgement} (membuat keputusan moral). Kompas.com melalui teks beritanya memuat klaim-klaim moral untuk memperkuai bingkainya. Hal ini dapat terlihat dalam teks berita berikut:

..Savic juga mengingatkan, Indonesia merupakan negara pluralistis yang masyarakatnya terdiri dari berbagai suku dan agama. (Larangan Warung Buka SAat Bulan Puasa Dinilai Merusak Citra Islam dan Toleransi)

Kisah Saeni harus mendapatkan perhatian pemerintah. Kebijakan dan peraturan seharusnya tidak memberatkan rakyat kecil seperti Saeni, dan yang lebih penting toleransi seharusnya hanya bisa ditunjukksn 
dengan sikap toleran, bukan dengan sebuah larangan. (Polemik Razia Warung Nasi)

\section{Treatment Recommendation} (Penyelesaian masalah). Berdasarkan latar belakang pendefinisian masalah,menentukan siapa penyebab masalah ataupun korban, klaim-klaim moral yang digunakan, Kompas.com merekomendasikan penyelesaian masalah berupa penghapusan Perda No.2 tahun 2010 tentang Pencegahan, Pemberantasan dan Penanggulangan Penyakit Masyarakat (Pekat) karena dianggap tidak cocok diterapkan di Negara Kesatuan Republik Indonesia.

\section{Frame Pemberitaan Republika.co.id}

Define Problem, berbeda dengan

Kompas.com, Republika.co.id membawa kasus Ibu Saeni vs Satpol PP ke ranah moral. Hal ini dapat terlihat dari pernyataan narasumber yang dipilih Republika.co.id, antara lain Ippho Santosa (Pakar otak kanan sekaligus penulis buku), Solihin Abas (Ketua Umum Forum Komunikasi Alumni Ikatan Mahasiswa Muhammadiyah Provinsi Banten), Maigus Nasir (MUI Kota Padang), Muhammad Basri (Kasatpol PP),Anton Tabah Digdoyo (Ketua Badan Penanggulangan Penistaan Agama (Bakorpa)Dewan Pakar ICMI) dan Asadullah (Direktur Satpol PP dan Perlindungan Masyarakat Kementrian Dalam Negeri).

Diagnose Causes (Penyebab Masalah), Republika.co.id memposisikan Perda No.2 tahun 2010 dan Satpol PP sebagai korban. Hal ini dapat terlihat pada teks berita berikut:

Toleransi digaungkan dalam pemberitaan tersebut. Perda syariat yang mengatur jam buka warung makan selama Ramadhan dihajar habis-habisan. Satpol PP sebagai kepanjangan tangan Pemkot Serang dihujat karena dinilai bertindak kasar,tidak berprikemanusiaan. (Gaduh Toleransi Berpuasa).

Sekretaris Majelis Ulama Indonesia (MUI) Kota Padang, Maigus Nasir mengatakan larangan menjual makanan pada siang hari di bulan Ramadhan jangan dilihat dari segi yang sempit akan tetapi harus dilihat faedahnya terutama dalam mendidik generasi muda.

"Ada nilai edukasi yang tidak bisa diabaikan dalam hal ini karena kita berusaha memberikan suri tauladan kepada generasi muda agar berpuasa di bulan ramadhan ini," ujar dia di Padang, Senin (13/6).

Menurut dia jika para pedagang dibiarkan berjualan lalu ada orang dewasa makan pada siang hari di bulan puasa tentu akan memberikan contoh yang buruk terhadap generasi muda.

"Hal ini jangan dilihat dari sisi ekonomi atau Hak Asasi Manusia (HAM) untuk mendapatkan makanan pada siang hari akan tetapi kita lebih melihat ini dari aspek pendidikan moral yang saat ini jauh menurun," tambah dia. 
Ia menjelaskan dalam hal razia menjadi sesuatu yang penting mengingat hal ini merupakan kewajiban dari Satpol PP yang bertugas menegakkan peraturan daerah. "Namun kami berharap dalam melakukan razia Satpol PP menggunakan cara-cara yang baik dan penuh sopan santun," terang dia. (MUI: Larangan Penjual Makanan di Siang Hari Edukasi Generasi Muda, 16 Juni 2016 13:53)

Melalui konstruksi beritanya Republika.co.id ingin menanamkan ke benak khalayak bahwa tidak ada yang salah dengan Perda No.2 tahun 2010 tersebut. Berbeda dengan Kompas.com yang memandang bahwa Perda No.2 tahun 2010 sebagai "perda yang bermasalah" karena dianggap intoleran, Republika.co.id justru memandang positif akan keberadaan perda tersebut. Republika.co,id dalam konstruksi beritanya berusaha meyakinkan khalayak bahwa tidak ada yang salah dari perda tersebut. Perda No.2 tahun 2010 tersebut merupakan bagian dari aspirasi masyarakat Serang, Banten. Perda tersebut merupakan salah satu bentuk kearifan lokal masyarakat Kota Serang. Republika.co.id mencoba mengajak khalayak untuk tidak berpikir sempit, Republika.co.id menilai Perda no.2 tahun 2010 itu justru baik untuk mendidik generasi muda.

Untuk memperkuat bingkainya, Republika.co.id melakukan penonjolan pada aspek-aspek tertentu, seperti kata, kalimat, gambar atau foto dan citra tertentu yang ditampilkan dalam teks beritanya. Frasa dihajar habis-habisan mengandung arti diserang terus menerus. Dalam kasus Ibu Saeni vs Satpol PP, sebagian kalangan menganggap bahwa Perda No.2 tahun 2010 adalah perda bermasalah, dianggap intoleran dan tidak sesuai dengan iklim toleransi yang berlaku di Indonesia. Namun, Republika.co.id mencoba mematahkan pandangan tersebut lewat argument-argumen yang ada pada beritanya. Republika.co.id menggunakan frasa nilai edukasi yang berarti nilai pendidikan bagi generasi muda, sehingga khalayak jangan hanya memandang dari sisi sempit tentang larangan berjualan pada bulan Ramadhan, jangan hanya melakukan pendekatan dari sisi ekonomi ataupun HAM.

Republika.co.id juga mempertegas bingkainya bahwa apa yang dilakukan Satpol PP Serang sudah tepat, sesuai prosedur dan bukan merupakan sesuatu yang salah. Hal ini terlihat dalam teks berita berikut:

Direktur Satpol PP dan Perlindungan Masyarakat Kementerian Dalam Negeri, Asadullah menjelaskan, otoritas Kota Serang telah melakukan sosialisasi razia warung makan pada tiga hari sebelum pelaksanaan puasa kepada para pemilik warung makanan di kota itu. Hal ini untuk menjelaskan terkait ramainya soal warung Ibu Saeni yang disita Pol PP. (Penyitaan 
Dagangan Ibu Saeni Sesuai Prosedur, Senin, 13 Juni 2016 21:54)

Otoritas: kekuasaan yang sah yang diberikan kepada lembaga dalam masyarakat yang memungkinkan para pejabatnya menjalankan fungsinya, hal ini erat hubungannya dengan hak, wewenang, dan kewajiban pemerintah daerah untuk mengatur dan mengurus rumah tangganya sendiri sesuai dengan peraturan perundang-undangan yang berlaku. Sosialisasi: upaya untuk memasyarakatkan sesuatu (dalam hal ini aturan berjualan makanan ketika bulan Ramadhan) sehingga mudah dipahami, dihayati oleh masyarakat. Tiga hari, di sini Republika mencoba untuk mematahkan kesan bahwa Satpol PP arogan dan bertindak semena-mena.

"Ini sebenarnya ada missedkomunikasi juga, dikiranya barang diambil. Padahal jam empat sore barang bisa diambil lagi dengan menandatangani surat perjanjian agar tidak mengulangi. Jadi bukan disita terus tidak dikembalikan, bukan seperti itu," katanya menegaskan. (Penyitaan Dagangan Ibu Saeni Sesuai Prosedur, Senin, 13 Juni 2016 21:54)

Lewat kalimat tersebut Republika.co.id mencoba meyakinkan khalayak bahwa apa yang dilakukan Satpol PP sudah benar, sesuai aturan yang berlaku, Satpol PP juga sudah mengedepankan persuasi dalam bentuk sosialisasi aturan. Republika.co.id juga berusaha meluruskan duduk perkara dengan menampilkan kutipan pernyatan untuk memperkuat bingkainya bahwa yang terjadi di lapangan bukan penyitaan barang dagangan yang kemudian tidak dikembalikan. Republika memilih frase missedkomunikasi yang berarti terjadi salah pengertian atas isu yang berkembang selama ini.

Republika.co.id memposisikan media massa dan kalangan penentang perda sebagai penyebab masalah. Hal ini dapat terlihat dalam teks berita berikut ini:

Perda berasal dari aspirasi rakyat setempat.

Setuju atau tidak, inilah Perda. Selama Ramadhan, rumah makan di beberapa kota, termasuk Serang, diminta untuk tidak beroperasi siangsiang, cukup sore dan malam saja. Di berbagai kota di Sumatera juga begitu, dengan atau tanpa Perda. Anda protes? Tunggu dulu. Apakah Anda penduduk Serang?Apakah pendapat Anda penting bagi warga Serang?Jika tidak,yah diam saja.Hargai.

Boleh-boleh saja kita berempati dan berdonasi kepada si ibu-ibu itu. Apalagi setelah digiring dan didramatisir oleh media.

Lantas bagaimana dengan mereka yang tidak berpuasa? Nonmuslim, musafir, orang sakit, muslimah haid, hamil, dan menyusui. Tenang. Mereka telah mengantisipasi. Aman kok. Terbukti mereka tetap tinggal di sana selama bertahuntahun. Nggak protes. Kok kita orang luar yang sok tahu dan mau 
menggurui?

(GaduhToleransi

Berpuasa, Pernah Nyepi di Bali?) Make moral judement Republika.co.id terlihat dalam teks berikut ini:

Sebagai konsepsi otonomi daerah dan dalam menjaga kearifan lokal Kota Serang pihak-pihak luar Banten diminta jangan coba mengintervensi. Biarlah Banten mengurus 'rumah tangga'-nya sendiri dan menjaga nilai-nilai sosial masyarakatnya. "Perda itu berlaku untuk Kota Serang, bukan Jakarta atau daerah lainnya. Selama ini tidak ada penolakan dari masyarakat di Kota Serang pada perda tersebut," kata Solihin. Dia mengatakan sejak perda itu disahkan pada 2010, bahkan jauh sebelum itu masyarakat Banten sudah mengerti soal menjaga toleransi. (Pihak Luar Jangan Intervensi 'Perda Pekat' di Serang)Treatment recommendation (rekomendasi penyelesaian masalah): pertahankan Perda No.2 tahun 2010.

Tabel 1 Frame Perbandingan Kompas.com dan Republika.co.id

\begin{tabular}{|c|c|c|}
\hline Elemen & Kompas.com & $\begin{array}{l}\text { Republika. } \\
\text { co.id }\end{array}$ \\
\hline Frame & \begin{tabular}{l}
\multicolumn{2}{l}{ Konstruksi } \\
Perda $\quad$ No.2 \\
Tahun \\
pada \\
Pemberitaan Ibu \\
Saeni rersus
\end{tabular} & $\begin{array}{l}\text { Konstruks } \\
\text { i Perda } \\
\text { No. } 2 \\
\text { Tahun } \\
2010 \text { pada } \\
\text { Pemberita } \\
\text { an Ibu }\end{array}$ \\
\hline
\end{tabular}

\begin{tabular}{|c|c|c|}
\hline & Satpol PP & $\begin{array}{l}\text { Saeni } \\
\text { versus } \\
\text { Satpol PP }\end{array}$ \\
\hline $\begin{array}{l}\text { Problem } \\
\text { Identification }\end{array}$ & HAM & Moral \\
\hline $\begin{array}{l}\text { Causal } \\
\text { Interpretation }\end{array}$ & $\begin{array}{l}\text { Penyebab } \\
\text { masalahnya } \\
\text { adalah Perda } \\
\text { no.2 tahun } \\
2010 \text {, dan Ibu } \\
\text { Saeni sebagai } \\
\text { korban. }\end{array}$ & $\begin{array}{l}\text { Perda no. } 2 \\
\text { tahun } \\
2010 \text { dan } \\
\text { satpol pp } \\
\text { sebagai } \\
\text { korban, } \\
\text { media } \\
\text { massa } \\
\text { (wartawan } \\
\text { ) sebagai } \\
\text { penyebab } \\
\text { masalah. }\end{array}$ \\
\hline Moral Evaluation & $\begin{array}{l}\text { Indonesia } \\
\text { negara proralis } \\
\text { dengan } \\
\text { semboyan } \\
\text { Bhinneka } \\
\text { tunggal Ika, } \\
\text { bukan negara } \\
\text { Islam. }\end{array}$ & $\begin{array}{l}\text { Biarlah } \\
\text { Banten } \\
\text { mengurus } \\
\text { 'rumah } \\
\text { tangganya } \\
\text {, sendiri, } \\
\text { pihak di } \\
\text { luar } \\
\text { Banten } \\
\text { tidak perlu } \\
\text { intervensi. }\end{array}$ \\
\hline $\begin{array}{l}\text { Treatment } \\
\text { Recommendation }\end{array}$ & $\begin{array}{ll}\text { Hapuskan } & \text { Perda } \\
\text { No.2 } & \text { tahun } \\
2010 & \end{array}$ & $\begin{array}{l}\text { Pertahank } \\
\text { an Perda } \\
\text { No. } 2 \\
\text { tahun } \\
2010\end{array}$ \\
\hline
\end{tabular}




\section{KESIMPULAN}

1. Berita merupakan hasil konstruksi dari wartawan. Berita bukanlah sesuatu yang bebas nilai. Seseorang dalam hal ini wartawan berlaku berdasarkan frame of reference dan field of experience-nya. Peristiwa yang sama bisa ditampilkan dengan cara berbeda seperti pada pemberitaan Ibu Saeni vs Satpol PP.

2. Saat mengkonstruksi sebuah peristiwa wartawan memilih faktafakta apa saja yang akan ditampilkan sekaligus juga menyembunyikan fakta-fakta yang ada untuk memperkuat bingkainya.

3. Kompas.com membingkai peristiwa Ibu Saeni vs Satpol PP ke ranah HAM. Kompas.com memposisikan Ibu Saeni sebagai Korban sedangkan penyebab masalahnya ditujukan kepada Perda No.2 tahun 2010 dan Satpol PP. Kompas memberikan klaim-klaim moral berupa Indonesia Negara pruralis, dengan semboyan Bhinneka Tunggal Ika, bukan Negara Islam. Penyelesaian masalah yang direkomendasikan Kompas.com adalah cabut Perda No.2 Tahun 2010.
1. Republika.co.id membingkai peristiwa Ibu Saeni vs Satpol PP ke ranah moral. Republika.co.id mendefinisikan media sebagai penyebab masalah, dan Perda No.2 tahun 2010 serta Satpol PP sebagai Korban. Republika.co.id memberikan klaim moral berupa biarlah Banten mengurus 'rumah tangganya' sendiri, pihak di luar Banten tidak perlu intervensi. Penyelesaian masalah (treatment recommendation) berupa pertahankan Perda No.2 Tahun 2010.

\section{DAFTAR PUSTAKA}

Eriyanto. 2002. Analisis Framing: Konstruksi, Ideologi, dan Politik Media. Yogyakarta: Lkis Printing Cemerlang.

Kriantono, Rachmat. 2006. Teknik Praktis Riset Komunikasi. Jakarta: Kencana Prenada Media Group

Salim, Agus. 2001. Teori Paradigma Penelitian Sosial. Yogyakarta: Tiara Wacana.

Tamburaka, Apriadi. 2012. Agenda Setting Media Massa. Jakarta:Rajawali Pers

Vera, Nawiroh. 2010. Pengantar Komunikasi Massa. Tangerang: Renata Pratama Media 